\title{
The impact of chemical contaminants on biocenosis (ecotoxycological studies)
}

\author{
Magdalena Wróbel $^{1,{ }^{*}}$, Agnieszka Stojanowska ${ }^{1}$, Martyna Nosarzewska $^{1}$, Radosław \\ Rutkowski, and Justyna Rybak ${ }^{1}$
}

${ }^{1}$ Wrocław University of Science and Technology, Faculty of Environmental Engineering, Wybrzeże Wyspiańskiego 27, 50-370 Wrocław, Poland

\begin{abstract}
The analysis of the impact of PCC "Rokita" chemical industry on the natural environment has been studied. Samples of water, soil and sediment taken nearby industry were analyzed with ecotoxicological tests.. We used Avena sativa for study the impact of industry on producers and to evaluate soil quality. Additionally the commercial test, Phytotoxkit, test was conducted. Water quality was assessed using Tubifex tubifex and Daphnia magna/ Sediment's quality was assessed with the application of Ostracodtoxkit $\mathrm{F}$ test (Heterocypris incongruens). Conducted ecotoxicological tests proved that the studied area surrounding PCC "Rokita" is still contaminated with organic toxic compounds we observed mortality in water and soil of organisms tested. The fighest impact of toxicants was recorded for sediments suggesting accumulation of toxicants over many years.
\end{abstract}

\section{Introduction}

Nowadays, the chemical industries are developing extremely fast. Along with the expanding range of new products, pollution produced by factories is also growing which may have a negative impact on human and the entire biocenosis [1]. This impact comes from the interaction between contamination and the organism, population or biocenosis, which leads to the mortality of organisms, inhibition of growth or physiological functions. What is more, accumulated pollution can be additionally transformed into toxic products during metabolism process [2].

PCC "Rokita" was founded in 1946, in place of a former German factory, in order to produce various chemical products for war purposes. Due to its rapid development in terms of production and employment "Rokita" became one of the largest chemical plants in Poland in sixties of XX century. In 1976, an explosion occurred due to the connection of a tank with an oxide of ethyl to tanks with ammonia at the border station between Poland and the Federal Republic of Germany. The age XXI brought major changes due to the modernization concerning the process of chlorine formation. Environmental-friendly membrane technology was used, instead of the mercury installation which was harmful to the environment [3].

To determine the environmental contamination by toxic substances, chemical analyzes are used. Ecotoxicological tests are also frequently used, which allow to detect the presence

* Corresponding author: magdalena.wrobel@pwr.edu.pl 
and determine the influence of chemical compounds on living organisms. Thanks to them it is possible to obtain the reliable data and results regarding the quality of the environment [4].

The main aim of the presented work was to analyze the impact of PCC "Rokita" on the surrounding environment and therefore on human health. In order to evaluate the toxicity of the studied area, ecotoxicological tests of water, sediment and soil were conducted.

\section{Materials and methods}

All study sites were located near PCC "Rokita"in Brzeg Dolny, Lower Silesia (Poland). The profile of industry has changed over time depending on market demands [5]. This industry has been chosen to study because of its great impact on environment in the past, what is more some serious accidents took place (i.e. explosion, chlorine leakage in 2017). The contaminants that entered the environment were a serious threat to the ecosystem. Thus, after the improvement of working conditions, with the beginning of XXI century we could also expect the improvement of the environment surrounding this industry as PCC "Rokita" which primarily deals with the production of chlorine, chlorinated products organic compounds.

\subsection{Materials}

Description of sites presented in Table 1.

Table 1. Description of sites.

\begin{tabular}{|c|c|c|}
\hline Sample & Site & Coordinates \\
\hline \multirow{2}{*}{ Odra river } & the site was located near the PCC Rokita municipal plant, at a & $51^{\circ} 15^{\prime} 36.9^{\prime \prime} \mathrm{N}$ \\
& distance of about 800 m from the plant & $16^{\circ} 44^{\prime} 01.3^{\prime \prime} \mathrm{E}$ \\
\hline \multirow{2}{*}{ Soil } & \multirow{2}{*}{ the site was located at the gate of the plant from the west } & $\begin{array}{l}51^{\circ} 16^{\prime} 25.8^{\prime \prime} \mathrm{N} \\
16^{\circ} 43^{\prime} 52.0^{\prime \prime} \mathrm{E}\end{array}$ \\
\hline
\end{tabular}

\subsection{Methods}

\subsubsection{Tubifex tubifex}

Tubifex tubifex (Oligochaeta, Tubificidae), called sludge worm, is a cosmopolitan freshwater oligochaete. Its presence suggest healthy conditions of the aquatic environment [6]. Tests using T. tubifex were carried out to check the toxicity of water collected from the Odra river (according to standards ASTM E1706-04, ASTM E1706-95b) [7].

The solutions of water were prepared at concentrations of $100 \%, 50 \%, 25 \%, 12.5 \%$, $6.25 \%$, and control samples. Ten sludge worms were exposed to each concentration (tests were done in three replicates for each concentration). After 24 hours, $48 \mathrm{~h}$ the mortality of organisms was analyzed. Worms were considered dead when they were completely immobilized.

\subsubsection{Avena sativa}

In ecotoxicological studies of the soil, mainly plants are used [2]. In this paper we have chosen Avena sativaaccording to the polish standard PN-ISO 11269-2:2001) [8]. The samples were prepared in the following concentrations: $100 \%, 50 \%, 25 \%, 12.5 \%, 6.25 \%$ and reference soil. The samples of the soil were placed in the small containers and then ten 
oat seeds were planted in each pot. The test was carried out in triplicate for each concentration. After seven days we assessed the quality of seed germinated and measured the shoot and root length.

\subsubsection{Ostracodtoxkit $F$}

Ostracod exposure tests were conducted in the form of 6 replicates per site sample and 1 control per sample by using reference sediment according to the standard operating procedures of the test kit. Ostracod neonates of the benthic ostracod crustacean Heterocypris incongruens were exposed to test sediments $\left(6\right.$ days in darkness at $25^{\circ} \mathrm{C}$ $\pm 2^{\circ} \mathrm{C}$ ). At the end of the test period, all surviving ostracods were counted and measured with micrometre cover slip. Growth inhibition of surviving ostracods exposed 6 days to studied sediments was determined in relation to (non-toxic) reference sediment. The percentage mortality was also determined [9].

\subsubsection{Seed germination and early growth microbiotest with higher plants}

Phytotoxkit test measures the decrease (or the absence) of seed germination and of the growth of the young roots after a few days of exposure of seeds of selected higher plants to toxicants or to contaminated soils.

The test was conducted in accordance with the procedure recommended by the manufacturer MicroBioTests Inc. $90 \mathrm{ml}$ of reference soil and tested soils were placed in triplicates on the lower compartment of the test plates $(21 \times 15.5 \times 0.8 \mathrm{~cm})$ and were hydrated with assessed volume of distilled water needed for complete hydration. The bottom part of the test plates were covered by a filter paper and then test seeds; monocotyl Sorghum saccharatum (Sorgho) were placed in a row at $1 \mathrm{~cm}$ below the middle ridge of the plates. The plates prepared in this way were incubated in a horizontal position at $25^{\circ} \mathrm{C}$ in darkness for $72 \mathrm{~h}$. Then, photos of the test plates were taken with a digital camera. Root lengths were subsequently measured with the aid of the Image $J$ program [10].

\subsubsection{Daphnia magna}

Daphnia magna is commonly used to assess acute toxicity in a $24-48 \mathrm{~h}$ assay based on immobility or mortality of the test organisms. Daphnids were obtained from the pet shop and the species was positively identified before testing. Test organisms were at similar age and size Using a wide bore pipette, thirty actively swimming daphnids were carefully placed into petri dishes. Then, containers were filled with undiluted samples of tested waters (breeding water was used as a control). After $24 \mathrm{~h}$ incubation at $20^{\circ} \mathrm{C}$ in darkness, the mortality and survival of daphnids were recorded.

\section{Results and discussion}

\subsection{Results of toxicity testing: water}

In the table 2. the mortality of the sludge worms T. tubifex in water is shown.

The biggest mortality was observed at the concentration of $100 \%$ (after 72 hours more than $50 \%$ of all worms were dead), which indicates the toxicity of the water from Odra river. At the concentration of $50 \%$ more than $60 \%$ of worms did not show any movement. At the concentrations of $25 \%, 12.5 \%$ and $6.25 \%$ the mortality was not strong and did not exceed $50 \%$. In control, T. tubifex showed typical movement and remained active until the end of test period. Additionally, we assessed the toxicity of water with D. magna. 
Table 2. The number of alive worms after 24,48 and 72 hours.

\begin{tabular}{|c|c|c|c|}
\hline Concentration, \% & $\mathbf{2 4} \mathbf{~ h}$ & $\mathbf{4 8} \mathbf{~}$ & $\mathbf{7 2} \mathbf{~ h}$ \\
\hline 100 & 20 & 15 & 14 \\
\hline 50 & 25 & 20 & 18 \\
\hline 25 & 30 & 25 & 22 \\
\hline 12.5 & 30 & 27 & 25 \\
\hline 6.25 & 30 & 27 & 26 \\
\hline control & 30 & 30 & - \\
\hline
\end{tabular}

Table 3. Percentage of mortality during $24 \mathrm{~h}$ of the experiment.

\begin{tabular}{|c|c|}
\hline Sample & Mortality, \% \\
\hline Conrol & - \\
\hline $\begin{array}{l}\text { Tested } \\
\text { water }\end{array}$ & 30 \\
\hline
\end{tabular}

This results shows that Odra river is slightly toxic (percentage mortality is $30 \%$ ), but the calculation of $\mathrm{LC}_{50}$ was impossible.

\subsection{Results of toxicity testing: soil}

The results of ecotoxicological test with $A$. sativa on soil are shown in the table 4 .

Table 4. Results of shoot and root length in A. sativa.

\begin{tabular}{|c|c|c|c|c|c|c|}
\hline $\begin{array}{c}\text { Concentration } \\
(\%)\end{array}$ & $\begin{array}{c}\text { replicate } \\
\mathbf{1}(\mathbf{c m})\end{array}$ & $\begin{array}{c}\text { replicate } \\
\mathbf{2}(\mathbf{c m})\end{array}$ & $\begin{array}{c}\text { Replicate } \\
\mathbf{3}(\mathbf{c m})\end{array}$ & $\begin{array}{c}\text { Average } \\
\text { shoot } \\
\text { length } \\
\text { (cm) }\end{array}$ & $\begin{array}{c}\text { Average } \\
\text { root } \\
\text { length } \\
\text { (cm) }\end{array}$ & $\begin{array}{c}\text { Numbers } \\
\text { of } \\
\text { germinated } \\
\text { seeds } \\
\text { (max. 30) }\end{array}$ \\
\hline 100 & 2.0 & 3.0 & 4.6 & 3.2 & 1.4 & 13 \\
\hline 50 & 11.5 & 14.7 & 12.1 & 12.8 & 5.5 & 21 \\
\hline 25 & 15.2 & 17.0 & 12.8 & 15.0 & 6.1 & 19 \\
\hline 12.5 & 14.6 & 11.6 & 14.3 & 13.5 & 5.9 & 20 \\
\hline 6.25 & 16.0 & 17.0 & 15.7 & 16.2 & 6.3 & 16 \\
\hline $\begin{array}{c}\text { control/reference } \\
\text { sample }\end{array}$ & 17.5 & 17.5 & 16.0 & 17.0 & 6.7 & 30 \\
\hline
\end{tabular}

At the concentration of $100 \%$ more than $50 \%$ of the seeds did not germinate. Percentage of germinated seeds varied. The average shoot length was only about $3 \mathrm{~cm}$ and average root length was $1.4 \mathrm{~cm}$ in the contaminated soil (100\% concentration). $\mathrm{ID}_{50}$ was $100 \%$ The shoot length in the reference soil was $17 \mathrm{~cm}$ on average and 6.7 for roots, respectively. 
We also assessed the soil toxicity with the application of Phytotoxkit. The results of this seed germination and early growth microbiotest with Sorghum saccharatum are shown in Table 5 .

Table 5. The percentage of growth inhibition of roots for Sorghum saccharatum.

\begin{tabular}{|c|c|}
\hline Sample & Percentage growth inhibition of roots, \% \\
\hline Control & 39.31 \\
\hline $\begin{array}{c}\text { Tested } \\
\text { soil }\end{array}$ & 31.38 \\
\hline
\end{tabular}

Phytotoxkit shows that the length of sorghum roots was slightly smaller in the tested sample, although the calculation of $\mathrm{IC}_{50}$ was not possible.

\subsection{Results of toxicity testing: sediments}

In order to assess the chronic toxicity of Odra sediments Ostracodtoxcit $\mathrm{F}$ was performed. We have measured the length of $H$. incongruens on the $1^{\text {st }}$ and $6^{\text {th }}$ day of the experiment and the percentage of mortality and percentage of growth inhibition was determined. The results are shown in Table 6.

Table 6. The results of Ostracodtoxkit F.

\begin{tabular}{|c|c|c|c|c|}
\hline Site & $\begin{array}{c}\text { The average length of } \\
\text { the body day } \mathbf{0}[\mathrm{mm}]\end{array}$ & $\begin{array}{c}\text { The average length of } \\
\text { the body day } \mathbf{6}[\mathrm{mm}]\end{array}$ & $\begin{array}{c}\text { Mortality } \\
{[\%]}\end{array}$ & $\begin{array}{c}\text { Growth } \\
\text { inhibition } \\
{[\%]}\end{array}$ \\
\hline Control & 232 & 833 & - & - \\
\hline $\begin{array}{c}\text { Odra } \\
\text { river }\end{array}$ & 232 & 492 & 35 & 57 \\
\hline
\end{tabular}

This test shows that the sediment from the river is toxic as we recorded smaller body length of organisms tested (492mm on average comparing to control $833 \mathrm{~mm}$ ) and we recorded inhibition growth $(57 \%)$ and quite high crustacean mortality (35\%).

\subsection{Discusion}

To sum up the obtained results, the acute toxicity was observed for water samples with $T$. tubifex in raw water, although other concentrations did not show such high impact of pollutants on water quality. Additional test with $D$. magna did not allow to calculate $\mathrm{LC}_{50}$ but the results were lower comparing to control samples. Tests conducted on soil also revealed the impact of contaminants on plant growth, especially for A. sativa, plants which was selected for studies. Similarly, the calculation of ID $_{50}$ was possible only for $100 \%$ of soil concentration for shoot and root length of $A$. sativa. Additional test, done with commercial Phytotoxkit showed only slight inhibition of root growth in S. saccharatum. The promising results were obtained when assessing the sediments toxicity (derived from Odra river). The growth inhibition $(57 \%)$ and mortality $(35 \%)$ of $H$. incongruens when 
applying Ostracodtoxcit $\mathrm{F}$ suggesting the existing impact of accumulated previously used chemicals in sediments on water biocenosis, as PCC "Rokita" mainly dealt and still deals with the production of chlorine and chlorinated products, organic compounds. Although the chemical industry is constantly evolving, and takes its impact on the natural environment into consideration $[3,11]$. On the other hand, chemical industries, such as PCC "Rokita" annually produce thousands of substances with an effect unknown to the environment and humans. The performed tests in this study indicate that toxicity around the area of this industry still exists, but it is not as high as used to be in the past. According to the report on the state of the environment for Lower Silesian Voivodship [12, 13], PCC "Rokita" maintains a tendency to decrease concentrations of various pollutants and it is constantly improving technologically, which might be the reason why toxicity in this area is not as severe as used to be before $[14,15]$.

\section{Conclusions}

1. We observed water toxicity in studied area as the mortality of the T. tubifex was observed. The $\mathrm{LC}_{50}$ was calculated for $100 \%$ concentration (pure water without dilutions) only. The mortality of other studied species D. magna did not exceed $50 \%$ of the population

2. For soil, we recorded inhibition of shoot and root growth for $A$. sativa. The $\mathrm{IC}_{50}$ was calculated for pure soil (no dilution) In commercial test, Phytotoxkit, only slight root inhibition growth was observed comparing to control for $S$. saccharatum.

3. Sediments studies based on commercial test Ostracodtoxkit $F$ revealed a negative impact on growth and survival of tested animals, which suggest that organic compounds accumulated in decades could have still impact on water environment.

4. The conducted ecotoxicological tests showed that the studied area near PCC "Rokita" S.A. still needs to be monitored and cleaned.

The investigations were co-financed within the framework of order No. 0401/0056/18 with a specific subsidy granted to the Faculty of Environmental Engineering, Wroclaw University of Science and Technology (W-7), by the Minister of Science and Higher Education.

\section{References}

1. A. Sobczak, Environmental Medicine 15, 7-17 (2012)

2. T. Traczewska, Biologiczne metody oceny skażenia środowiska $(15-34,2011)$

3. D. Łaba, Chemia Przemysłowa 3, 76-77 (2012)

4. A. Valavanidis, T. Vlachogianni, Science Advances on Environmental Chemistry, Toxicology and Ecotoxicology, 1-29 (2015)

5. J. Rogala, Historia Zakładów Chemicznych Rokita S. A. $(1-6,1996)$

6. K. A. Beauchamp, R. D. Kathman, T. S. McDowell, R. P. Hedrick, Molecular Phylogenetics and Evolution 19, 216-224 (2001)

7. C. Amiard-Triquet, J. C. Amiard, C. Mouneyrac, Aquatic ecotoxicology Advancing Tools for Dealing with Emerging Risks (2015)

8. PN-ISO 11269-2:2001 Jakość gleby - Oznaczanie wpływu zanieczyszczeń na florę glebową - Część 2: Wpływ zanieczyszczonej gleby na wschody i wczesny wzrost roślin wyższych 
9. OSTRACODTOXKIT F Chronic "direct contact" toxicity test for freshwater sediments. Standard Operational Procedure (2017)

10. PHYTOTOXKIT $F$ test in assessment of toxicity of two types of sewage sludge standard operational procedure (2017)

11. Y. C. Cloete, B. F. Shaddock, A. Nel, Water SA. 43, 409 (2017)

12. L. A. Maranho, L. T. Maranho, R. G. Botelho, V. L. Tornisielo, Arch. Environ. Contam. Toxicol. 65, 319-320 (2014)

13. A. Antosz, E. Banach, L. Barański, R. M. Ciechanowicz-Kusztal, Raport o stanie środowiska w województwie dolnośląskim w 2001 roku, 2, 5-8 (2001)

14. M. Bełcik, A. Trusz-Zdybek, E. Galas, K. Piekarska, Atmospheric Environment 95, 620-628 (2014)

15. A. Trusz, M. Wolf-Baca, A. Siedlecka, Inżynieria Ekologiczna 19, 4, 51-57 (2018) 